\title{
Mathematical modelling of the thin layer drying of pineapple (Ananas comosus, L.): experiment at village-scale in a greenhouse type solar dryer \\ Modelo matemático de la capa delgada de piña (Ananas comosus, L.): Experimento en un secador solar tipo invernadero a gran escala
}

\author{
López-Cerino Ignacio \\ Universidad Autónoma Chapingo \\ E-mail: cerino3@gmail.com \\ http://orcid.org/0000-0002-3668-7735 \\ López-Cruz Irineo Lorenzo \\ Universidad Autónoma Chapingo \\ E-mail:ilopez@correo.chapingo.mx \\ http://orcid.org/0000-0003-0630-6257 \\ Janjai Serm \\ Universidad de Silpakorn, Tailandia \\ Facultad de Ciencias \\ E-mail: serm@su.ac.th \\ http://orcid.org/0000-0002-8797-4283
}

\author{
Mahayothee Busarakorn \\ Universidad de Silpakorn, Tailandia \\ Facultad de Ingeniería y Tecnología Industrial \\ E-mail: busarakornm@yahoo.com \\ http://orcid.org/0000-0001-8600-8051 \\ Nagle Marcus \\ Universidad de Hohenheim, Alemania \\ E-mail: marcus.nagle@uni-hohenheim.de \\ http://orcid.org/0000-0003--0253-1537 \\ Müller Joachim \\ Universidad de Hohenheim, Alemania \\ E-mail: joachim.mueller@uni-hohenheim.de \\ http://orcid.org/0000-0003-4623-5879
}

\begin{abstract}
The objectives of this research were two: first to investigate experimentally the behavior of pineapple (Ananas comosus, L.) thin layer drying in a greenhouse-type solar dryer and second to describe the best fitting kinetic and mathematical model taken from literature. A large scale greenhouse dryer designed and installed at Silpakorn University, Nakhon Pathom, Thailand was used to dry slices $1 \mathrm{~cm}$ width at temperature range between $25-60{ }^{\circ} \mathrm{C}$ with relative humidity between $50-90 \%$. Nine statistical models, either empirical or semi-empirical, were tested in order to validate the experimental data. A non-linear regression analysis conducted by a statistical computer program was applied to evaluate the constants of all the models. The parameter values, root mean square error (RMSE), mean absolute error (MAE) and modelling efficiency (EFF) of the nine models were calculated. Comparison outcomes of two experiments are displayed between the predicted moisture content and the observed pineapple moisture content. Hasibuan and Daud drying model proved to describe the best pineapple solar drying curves. The two experiments were carried out on sunny days, the second experiment on the third day showed cloudiness decreasing the solar radiation. Mathematical models of pineapple drying in a greenhouse dryer have not been found so far in the literature. Drying curves obtained from experiments showed that the constant drying and the falling drying rate periods exist. Nine thin-layer drying models were fitted to two experimental data in order to describe the drying characteristics of pineapple founding that the Hasibuan and Daud model was the best fitting.
\end{abstract}

Keywords: Ananas comosus, thin-layer drying, drying models, greenhouse dryer.

\section{Resumen}

Los objetivos de esta investigación fueron dos: primero, investigar experimentalmente el comportamiento del secado de piña (Ananas comosus, L.) en capa delgada en un secador solar tipo invernadero y segundo, la descripción del modelo cinético y matemático de secado mejor ajustado tomado de la literatura. Se utilizó un invernadero a gran escala diseñado e instalado en la Universidad de Silpakorn, Nakhon Pathom, Tailandia, para deshidratar rebanadas de $1 \mathrm{~cm}$ de ancho en un rango de temperatura entre $25-60^{\circ} \mathrm{C}$ con una humedad relativa entre $50-90 \%$. Se ajustaron los datos experimentales con nueve modelos estadísticos tanto empíricos como semi-empíricos a fin de describir las características de secado de piña. Un análisis de regresión no lineal conducido por un programa estadístico fue aplicado para evaluar la constante de todos los modelos. Valores de los parámetros, raíz cuadrada del error cuadrado medio (RMSE), error absoluto medio (MAE) y eficiencia de modelado (EFF) de los nueve modelos fueron calculados. Se presentan los resultados para dos experimentos de las comparaciones realizadas entre el contenido de humedad predicho con el contenido de humedad observado en la piña. El modelo de secado Hasibuan y Daud presentó el mejor ajuste de las curvas de secado solar de la piña. Los dos experimentos se llevaron a cabo en días soleados, el segundo experimento al tercer día presentó nubosidad disminuyendo la radiación solar. Modelos matemáticos de secado de piña en un secador solar tipo invernadero no se han encontrado en la literatura. Curvas de secado se obtuvieron de los experimentos mostrando que existe secado constante y periodos de caída de la razón de secado. Nueve modelos de secado en capa delgada fueron ajustados en dos experimentos a fin de describir las características de secado de piña encontrándose que el modelo de Hasibuan y Daud fue el que mejor se ajustó.

Descriptores: Ananas comosus, secado en capa delgada, modelos de secado, secador tipo invernadero. 


\section{INTRODUCTION}

Pineapple (Ananas comosus L.) is the leading edible member of the family Bromeliaceae with about 2,000 species, mostly epiphytic and many strikingly ornamental. It is a terrestrial herb from 0.75 to $1.5 \mathrm{~m}$ high with a ramification of 0.9 to $1.2 \mathrm{~m}$; it has a very short stout stem and a rosette of waxy formed by sharp-pointed leaves from 50 to $180 \mathrm{~cm}$ long; the fruit has up-curved spines on its surface. Pineapples develop from the flowers joining together forming a cone shaped, juicy, fleshy fruit at least $30 \mathrm{~cm}$ height, Pineapple is usually treated in order to conserve the fruit by sugar syrup pre-treatment.

Thailand is located in the tropical region of Southeast Asia having annual average daily solar radiation of 18.2 MJ $\mathrm{m}^{-2}$ day $^{-1}$ (Janjai et al., 2006). Thus, the use of solar energy to produce high quality dried pineapple is in theory viable. Several studies about pineapple drying have been reported (Hossain et al., 2001; Talla et al., 2005; Simal et al., 2007; Kingsly et al., 2009; Ramallo and Mascheroni 2012; Agarry et al., 2013 and Olanipekun et al., 2014), but none of these has researched about solar dryer greenhouse type.

The design of an optimal solar drying system requires setting up particular drying requirements depending on the specific product to treat. Basic parameters including temperature, relative humidity, dimensions and airflow rate should be investigated. The prediction of performance of solar dryer, can be done using simulation models, which have been investigated by John and Sangamithra (2014).

In the current study, the thin layer drying behavior of pineapple in a greenhouse-type solar dryer for village-scale is investigated. Furthermore, the mathematical models that describe the thin layer drying curves are determined by non-linear regression analysis. A large scale greenhouse developed at Silpakorn University,
Nakhon Pathom, Thailand was used to dry $1 \mathrm{~cm}$ width slices in a temperature range between $25-60^{\circ} \mathrm{C}$ with relative humidity between $50-90 \%$. The purpose of this paper is to provide guidelines to preserve pineapple adequately by solar drying. The mathematical models can be applied in countries that have tropical climate.

\section{Materials AND METHODS}

\section{DRYING EXPERIMENTS}

\section{EXPERIMENTAL SET UP}

Greenhouse-type solar dryer for village-scale is designed and built at Silpakorn University, Nakhon Pathom, Thailand with a parabolic roof structure made from polycarbonate plate, established on a concrete floor: This dryer was used to carry out the experiments of pineapple drying. This is located at $14^{\circ} 01^{\prime} 42.5^{\prime \prime} \mathrm{N}$ latitude and $99^{\circ}$ $58^{\prime} 12.1^{\prime \prime} \mathrm{E}$ longitude. The product was placed in a thin layer with a total of three trays arrays. These were placed on single level platforms above floor with enough space in between for loading and unloading the product inside the dryer. A similar solar dryer for village-scale is fully described by Janjai et al. (2009). With three DC fans, operated by a 50-W PV-module, the air is ventilated from the greenhouse in order to remove humidity. Greenhouse solar dryer structure characteristics and dimension, as well as, sensors at correct position to measure temperature, relative humidity and samples weights are showed in Figure 1.

\section{EXPERIMENTAL PROCEDURE}

Two experiments of pineapple drying were carried out during the month of November 2014. The conditions were the same for both experiments with the exception

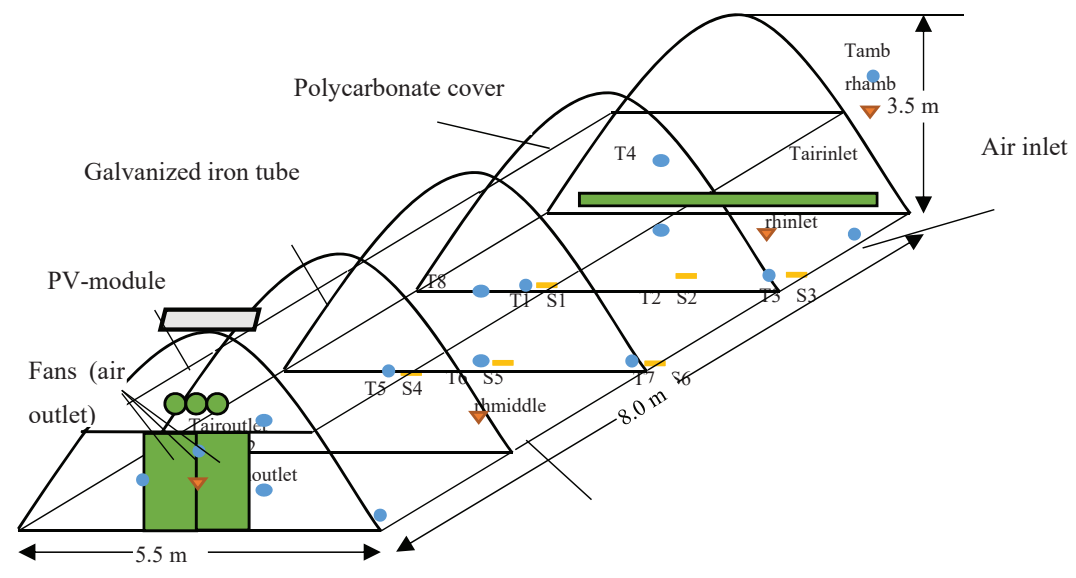

Figure 1. Respective locations of the thermocouples $(\mathrm{T})$, hygrometer (rh) and product samples for weights $(\mathrm{S})$ inside the structure of the dryer $5.5 \mathrm{~m}$ 
of the operational days. Pineapple was dried in order to get drying data that were required in fitting mathematical models in order to understand better and then to be capable of improving the solar drying process of pineapple in a greenhouse.

Thermocouples (K type, accuracy $\pm 2 \%$ ) were used to measure air temperature in the dryer at different locations. The thermocouple positions both for temperature and relative humidity are shown in Figure 1. Ambient air relativity humidity and drying air flow were measured using hygrometers (Electronik, model EE23, accuracy $\pm 2 \%$ ). Solar radiation was measured by a pyranometer (Kipp and Zonen CM 11, accuracy \pm $0.5 \%$ ). A multi-channel data logger (Yokogawa, model DC100) was used to record every 10 minutes a signal voltage from the pyranometer, hygrometers and thermocouples. The pyranometer and hygrometers were appropriately calibrated.

Pineapples utilized in this study were purchased in a local fruit market of Nakhon Pathom Province (Thailand). For each experiment a sample of $100 \mathrm{~kg}$ of pineapple was used, placed in the platforms early described in the greenhouse. Good quality fruits were selected to conduct a standardized solar drying experiment. For each fruit, the flesh was separated from the core and sliced into samples of $10 \mathrm{~mm}$ thick using an electrical slicer. These slices were uniformly laid out on the trays of the to perform the following solar drying process as seen in Figure 2. Experiment took place from 8:00 $\mathrm{h}$ to $18: 00 \mathrm{~h}$. Since the main objective was to reach the desire moisture content the drying process followed up during several days. At each one-hour interval, the samples were placed in several locations, which each of them were weighed using a digital balance (Kern, model $474-42$, accuracy $\pm 0.1 \mathrm{~g}$ ). The exact dry solid weight for each sample was obtained by oven method $\left(105^{\circ} \mathrm{C}\right.$ for 24 hours, accuracy $\pm 0.5 \%$ ).

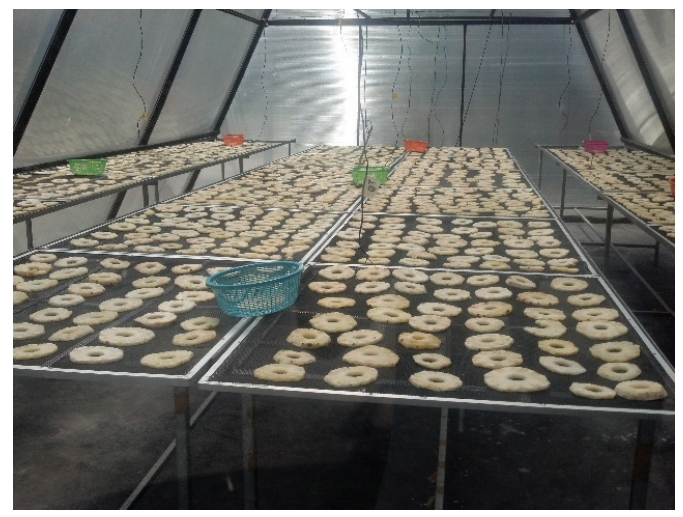

Figure 2. Pineapple slices uniformly laid out on trays for greenhouse solar drying operations

\section{MOISTURE CONTENT}

It was determined the moisture content $\left(M_{\text {mass }}, d b, \%\right)$ by mass which is defined as:

$$
M_{\text {mass }}=\frac{m_{w}}{m_{\text {material }}} \cdot 100 \%
$$

Where $m_{w v}(\mathrm{~kg})$ is the mass of water and $m_{\text {material }}(\mathrm{kg})$ the mass of the dry material, respectively.

The moisture present in the material originates, in general, from three sources: external water, internal liquid water and water vapor content in the surrounding air. Gravimetric determination is a direct method and the best and most absolute method for determining the average moisture content, i.e. to measure the sample weight before and after drying (Erich and Pel, 2011).

Weight difference between wet and dry sample is used for determination of the absolute moisture content $\left(M_{m}\right)$ in $\mathrm{kg} \mathrm{kg}^{-1}$.

$M_{m}=\frac{m_{w e t}-m_{d r y}}{m_{d r y}}$

Where $m_{\text {wet }}(\mathrm{kg})$ is the mass of the wet material and $m_{d r y}(\mathrm{~kg})$ the mass of the dry material.

\section{Mathematical modeling}

\section{CALCULATION OF MOISTURE RATIO}

Data obtained at different drying temperatures were transformed to the moisture ratio (MR) and is expressed as:

$M R=(M-M e) /\left(M 0-M_{e}\right)$

where: MR is the dimensionless moisture content ratio; $M$ and $M_{0}$, and $M_{e}$ are the moisture content at any given time, the initial moisture content and equilibrium moisture content respectively.

\section{DRYING MODELS}

Drying curves were generated by data collected from the greenhouse-type solar dryer; once they were developed they were fitted with nine empirical and semi theoretical thin-layer drying expressions (Table 1) taken from Ertekin and Firat (2015) because they represented an appropriate fitting for this type of drying experi- 
ments (Togrul and Pehlivan, 2002; Koua et al., 2009 and Janjai et al., 2012).

The equations were selected after evaluating nine and discarding the one with the highest Root Mean Squared Error (RMSE). The estimation of the parameters and RMSE with nonlinear regression was performed using the Optimization Toolbox of MatLab® (Version R2013b), this tool let us perform design optimization tasks, including parameter estimation, component selection and parameter tuning. The fitting results of logarithmic model were not adequate. Even though, Kingsly et al. (2009) argued that this model type produced a good prediction of the drying pineapple process.

\section{Statistical EVALUATION}

The RMSE was one of the main criteria in order to select the best fitting equation. RMSE should be low and it is defined as it follows:

$$
R M S E=\left[\frac{\sum_{i=1}^{N}\left\{M_{p r e, i}-M_{o b s, i}\right\}^{2}}{N}\right]^{0.5}
$$

Where $M_{p r e, i}$ and $M_{o b s, i}$ are the predicted and observed dimensionless moisture ratio respectively and $\mathrm{N}$ is the number of measurements. The Root Mean-Square Error (RMSE) is a kind of generalized standard deviation.

Another criterion for model selection was the mean absolute error (MAE), which was calculated as the difference between locations that are known and locations that have been interpolated or digitized; the MAE is a statistical measure of how far estimates or predicted values are from actual values. It avoids compensation between under- and over-prediction and it is given by:

$M A E=\frac{1}{n} \sum_{i=1}^{n}\left|f_{i}-y_{i}\right|=\frac{1}{n} \sum_{i=1}^{n}\left|e_{i}\right|$

Where $f_{i}$ is the prediction and $y_{i}$ the true value; $\left|e_{i}\right|$ is an average of the absolute errors. The units of MAE are the same as $y_{i}$; furthermore, there is no over-weighting of large differences here. Modeling efficiency (EF) considers distance measures that have an upper and/or lower bound to compare completely different cases (different data, different models) and it is defined as

$$
E F=1-\frac{\sum_{i=1}^{n}\left(y_{i}-f_{i}\right)^{2}}{\sum_{i=1}^{n}\left(y_{i}-\bar{Y}\right)^{2}}
$$

Where $\bar{Y}$ is the average of $y_{i}$.

\section{EQUILIBRIUM MOISTURE CONTENT}

In these experiments, equilibrium moisture content of pineapple slices was assumed when the mass became constant after a large period of time, temperature and relative humidity. The moisture content $\left(M_{i^{\prime}} d b, \%\right)$ of each pineapple sample was determined by means of its dry weight using equation 7 .

$M_{i}=\left(1+\frac{m f}{m i_{i} \times\left(\frac{M C f}{100}-1\right)}\right) \times 100 \%$

Table 1. Thin-layer drying models

\begin{tabular}{ll}
\hline \multicolumn{1}{c}{ Equation } & \multicolumn{1}{c}{ Name } \\
\hline 1. $M R=a \exp (-k t)+(1-a) \exp (-k b t)$ & Diffusion Approximation \\
2. $M R=\left[\frac{a+b^{*} t}{1+c^{*} t+d t^{2}}\right]$ & Haghi and Angiz - III \\
3. $M R=a \exp =\left[\frac{-(t-b)^{2}}{2 c^{2}}\right]$ & Haghi and Angiz - IV \\
4. $M R=1-a t^{n} \exp \left(-k t^{m}\right)$ & Hasibuan and Daud \\
5. $M R=a \exp \left(-k t^{n}\right)+\operatorname{cexp}\left(-g t^{n}\right)$ & Hii \\
6. $M R=a 0 /[1+a \exp (k t)]$ & Logistic \\
7. $M R=\exp \left(-k t^{n}\right)+b t$ & Modified Midilli - I \\
8. $M R=\exp \left(-k t^{n}\right)$ & Page \\
9. MR $=\exp \left(-k t^{n}\right)+b t+c$ & Sripinyowanich and Noomhorm \\
\hline
\end{tabular}


where the terms $m i_{i}(\mathrm{~g})$ and $m f(\mathrm{~g})$ refer to the initial mass and final dry mass respectively; $M C f(\%, \mathrm{db})$ refer to final moisture content.

\section{ResULTS AND DISCUSSION}

Two different pineapple greenhouse solar drying experiments were carried out: The first one took place from 19 to 21 November 2014 and the second one was from 24 to 26 November the same year. During the three days of pineapple drying, solar radiation was higher from 8:00 to 18:00 h. Solar radiation variation during the experimental run can be observed in Figure 3.

The internal and central temperature profiles in the greenhouse dryer type and the outside temperature are showed in Figure 4. It can be seen that the temperatures varied in a narrow band with exception of outside temperature where the differences were more significant. In the case of Figure 5, the behavior of the relative hu- midity of the inlet, outlet and surroundings can be seen. From this figure, it is clear that both conditions of experiment one (November 19, 20 and 21) and experiment two (November 24, 25 and 26) were similar.

\section{DRYING KINETICS}

Final moisture content of pineapple reached $22 \mathrm{db} \%$ (reached when three consecutive weight reading were constant during drying) in the greenhouse solar dryer type after three days of drying. The changes of moisture content for the two experiments are showed in Figure 6 and Figure 7. As can be observed a total of nine samples (MC1, MC2... MC9) were used to measure the mass of the product at each hour inside the greenhouse solar dryer type. Location of the sample inside the greenhouse dryer turned out not to be significant for the rate of drying, as can be seen in the results of Figure 6 and Figure 7.
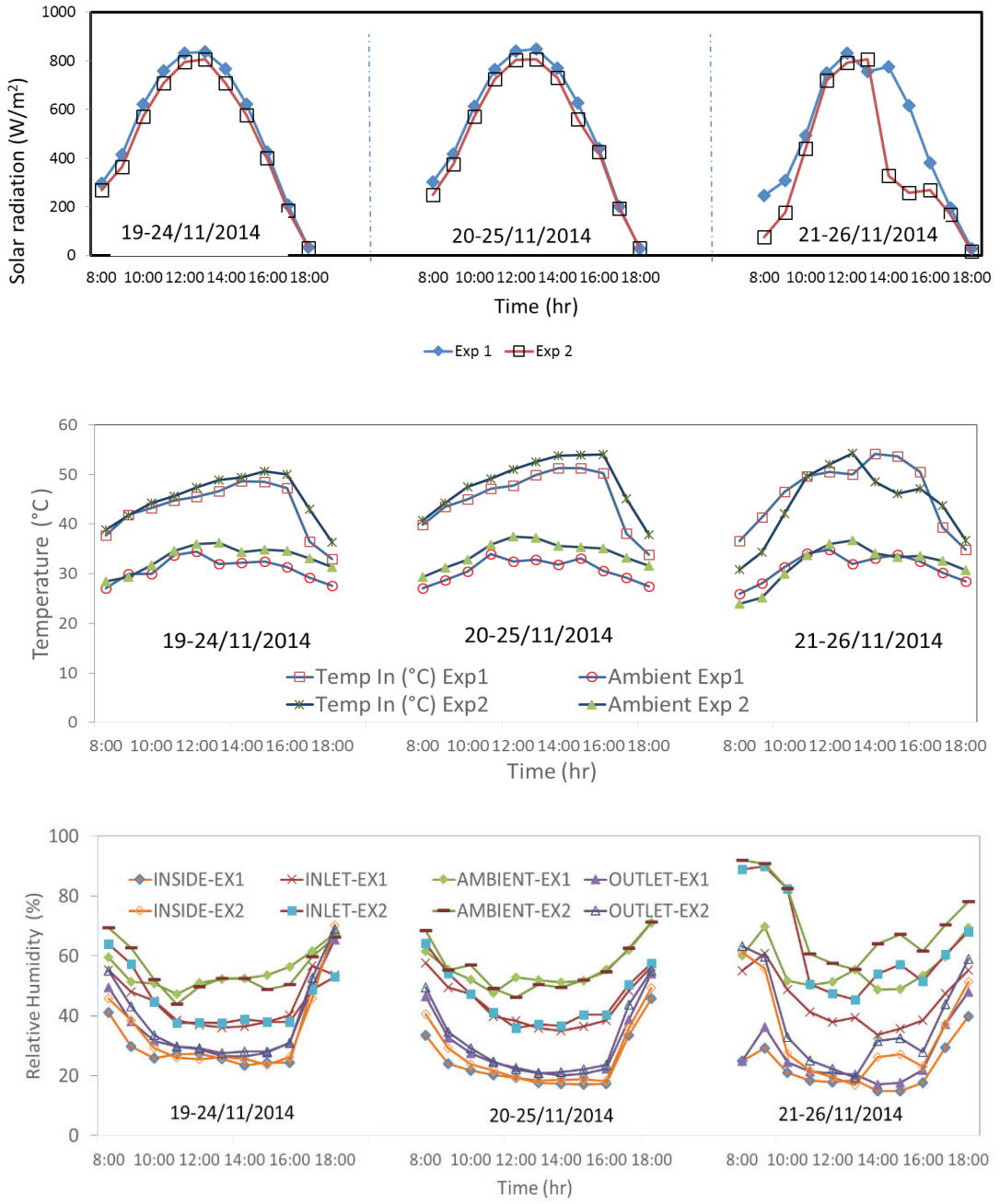

Figure 3. Hourly profile of solar radiation during pineapple drying experiments one and two

Figure 4. Behavior of temperature inside the greenhouse solar dryer (Temp In) and ambient temperature of pineapple in experiments one and two

Figure 5. Profiles of ambient relative humidity as well as at the dryer inlet, interior, and outlet of the greenhouse solar dryer for experiments one and two 

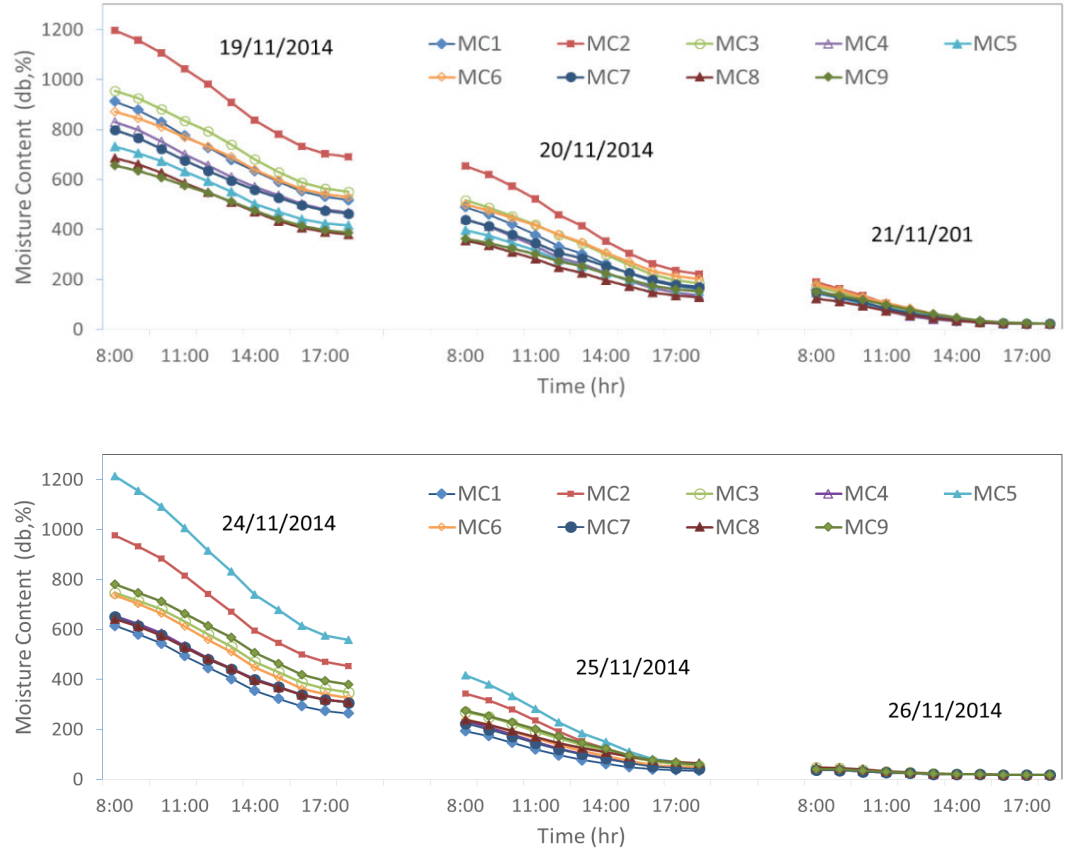

Figure 6. Behavior of the drying process of pineapple in the greenhouse solar dryer with sunny days in experiment one

\section{DRYING BEHAVIOR OF PINEAPPLE}

It can be observed that higher solar radiation allowed faster moisture desorption in comparison with lower radiation. Higher initial moisture removal rate can be observed at the first day in comparison with the removal rate during the following days. This is a typical moisture desorption behavior of food material, which has been reported by Olanipekun et al. (2014) as a short drying period constant rate and a steep declining rate period.

\section{MODELLING OF THIN-LAYER DRYING}

Moisture ratios of dried pineapples at different temperatures and air flows were fitted to nine thin layer models. Statistics values, RMSE, MAE and EF are shown in Table 2 for all them. Hasibuan and Daud model was the best followed by Sripinyowanich and Noomhorm and Modified Midilli. For these three cases the value of RMSE was less than $13.17 \%$ which means that an acceptable fitting was reached. The average value of RMSE for the Hasibuan and Daud model was $11.89 \%$, the MAE was 8.53 and $E F=0.96$.

\section{EVALUATION OF DRYING MODELS}

Nine thin-layer drying models were fitted to the experimental data of moisture ratio obtained in two different experiments, changing temperature, relative humidity and air velocity over time. Models are shown in Table 1. The parameter values, RMSE, MAE and EFF of the models are depicted in Table 2. The Hasibuan and Daud model was found to be the best, followed by the Sripinyowanich and Modified Midilli.

Comparisons between the predicted and experimental data of thin-layer drying for Hasibuan and Daud, Sripinyowanich and Modified Midilli can be seen in Figure 8. The agreement between the prediction and measured values of these models is fair. In contrast, using a high-precision dryer type allowed environmental variables to be controlled so that drying behavior can be determined under constant conditions, (Janjai et al. 2011; López et al., 2018); in case of the experiments which were carried under large-scale dryer conditions, it could not determine a relationship between the parameters of the models and environmental variables because they were not constant.

Validation of the best fitting model for Hasibuan and Daud was made by comparing the predicted moisture content with the experimental moisture content in any particular experiment of greenhouse solar dryer. The performance of the model is illustrated in Figure 9-10. For experiment one RMSE was equal to 12.13 and for experiment two RMSE was 10.72. The predicted data generally band around 1:1 straight line representing experimental data, which indicated the suitability of the Hasibuan and Daud mathematical model in describing drying behavior of pineapple applicable bet- 
ween the prediction and measured values. With these results, it is possible to make a recommendation regarding the use of the models to optimize the pineapple drying in other locations with similar temperature, relative humidity and air velocity using a greenhouse dryer like the one used in this research.

Table 2. Modelling of moisture content according to drying time for pineapple

\begin{tabular}{|c|c|c|c|c|c|c|c|c|c|c|c|c|c|}
\hline Models & Exp. & $\mathrm{a} 0(\mathrm{~h}-1)$ & a $(-)$ & $\mathrm{b}(-)$ & c $(-)$ & $\mathrm{d}(-)$ & $\mathrm{g}(\mathrm{h}-1)$ & $\mathrm{k}(-)$ & $\mathrm{m}(-)$ & $\mathrm{n}(-)$ & RMSE (\%) & MAE & $\mathrm{EF}$ \\
\hline \multirow{3}{*}{$\begin{array}{l}\text { Diffusion } \\
\text { Approximation }\end{array}$} & 1 & & -58.68 & 0.987 & & & & 0.134 & & & 27.041 & 21.616 & 0.736 \\
\hline & 2 & & -31.12 & 0.973 & & & & 0.193 & & & 14.658 & 9.771 & 0.952 \\
\hline & 1 & & 0.998 & -0.032 & 0.014 & 0.001 & & & & & 14.602 & 11.578 & 0.927 \\
\hline Haghi and Angiz-III & 2 & & 0.994 & -0.032 & 0.003 & 0.007 & & & & & 15.676 & 10.957 & 0.940 \\
\hline \multirow{2}{*}{$\begin{array}{l}\text { Haghi and Angiz- } \\
\text { IV }\end{array}$} & 1 & & 1.133 & -8.516 & 15.730 & & & & & & 18.534 & 15.471 & 0.866 \\
\hline & 2 & & 1.264 & -8.053 & 12.030 & & & & & & 12.173 & 9.290 & 0.958 \\
\hline \multirow{2}{*}{ Hasibuan and Daud } & 1 & & 0.056 & & & & & $4.386 \mathrm{E}-07$ & 3.784 & 0.887 & 12.661 & 9.695 & 0.949 \\
\hline & 2 & & 0.045 & & & & & 0.051 & 0.987 & 1.333 & 11.119 & 7.371 & 0.973 \\
\hline \multirow{2}{*}{ Hii } & 1 & & 0.245 & & 0.738 & & 0.002 & 0.045 & & 2.229 & 10.269 & 8.283 & 0.963 \\
\hline & 2 & & -56.03 & & 57.120 & & 0.167 & 0.169 & & 0.989 & 26.634 & 19.325 & 0.810 \\
\hline \multirow{2}{*}{ Logistic } & 1 & 1.27 & 0.308 & & & & & 0.139 & & & 20.757 & 17.258 & 0.833 \\
\hline & 2 & 1.396 & 0.392 & & & & & 0.183 & & & 12.189 & 8.538 & 0.964 \\
\hline \multirow{2}{*}{ Modified Midilli } & 1 & & & -0.075 & & & & -0.026 & & 1.011 & 12.986 & 10.453 & 0.940 \\
\hline & 2 & & & 0.000 & & & & 0.037 & & 1.399 & 13.093 & 8.642 & 0.963 \\
\hline \multirow{2}{*}{ Page } & 1 & & & & & & & 0.025 & & 1.378 & 24.799 & 20.892 & 0.763 \\
\hline & 2 & & & & & & & 0.037 & & 1.396 & 12.883 & 8.728 & 0.962 \\
\hline \multirow{2}{*}{$\begin{array}{l}\text { Sripinyowanich and } \\
\text { Noomhorm }\end{array}$} & 1 & & & -0.071 & 0.006 & & & -0.019 & & 1.082 & 13.171 & 10.349 & 0.942 \\
\hline & 2 & & & 0.001 & -0.016 & & & 0.036 & & 1.435 & 12.861 & 8.459 & 0.964 \\
\hline
\end{tabular}



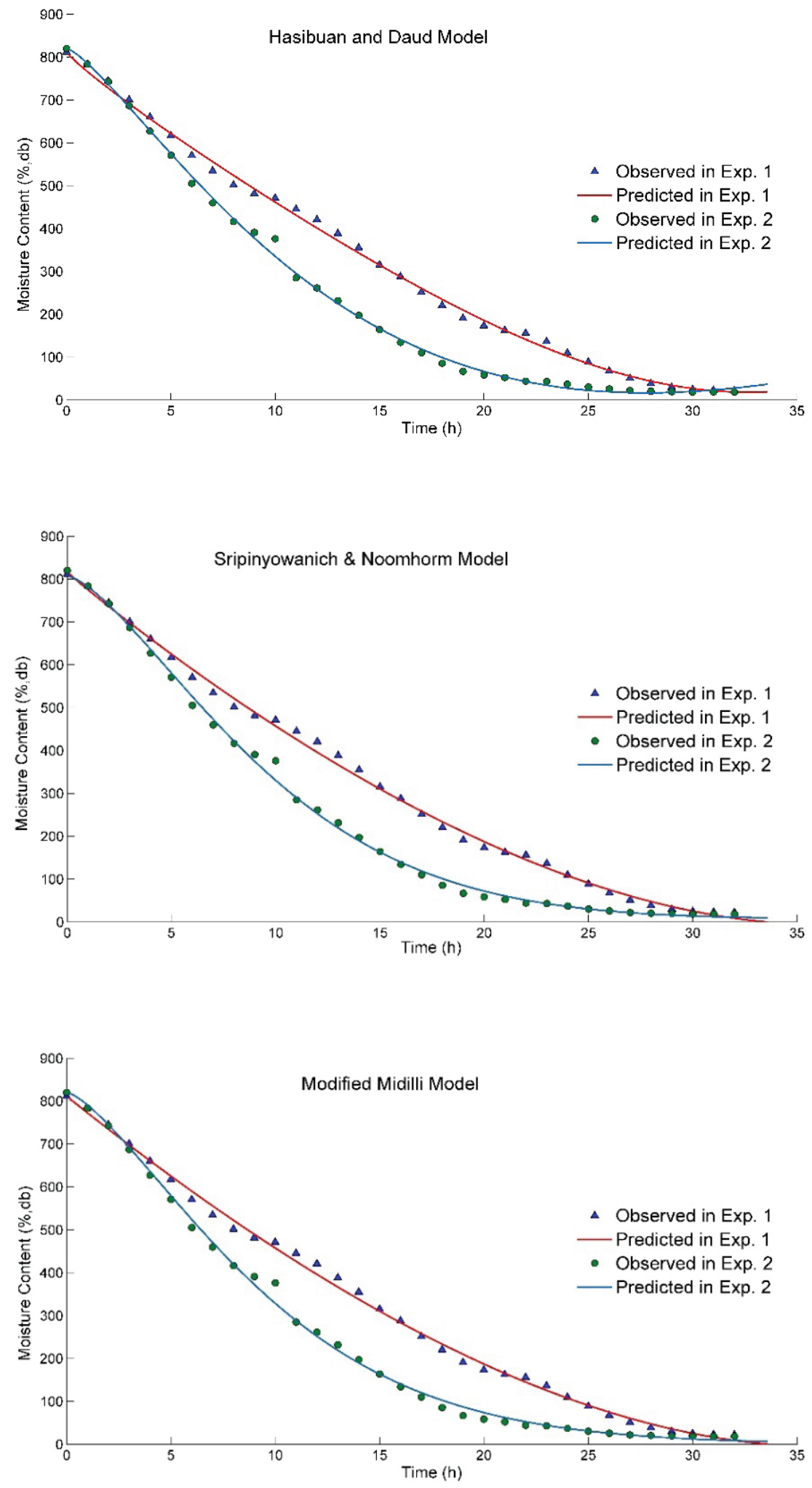

Figure 8. Thin layer drying of pineapple in experiments one and two 

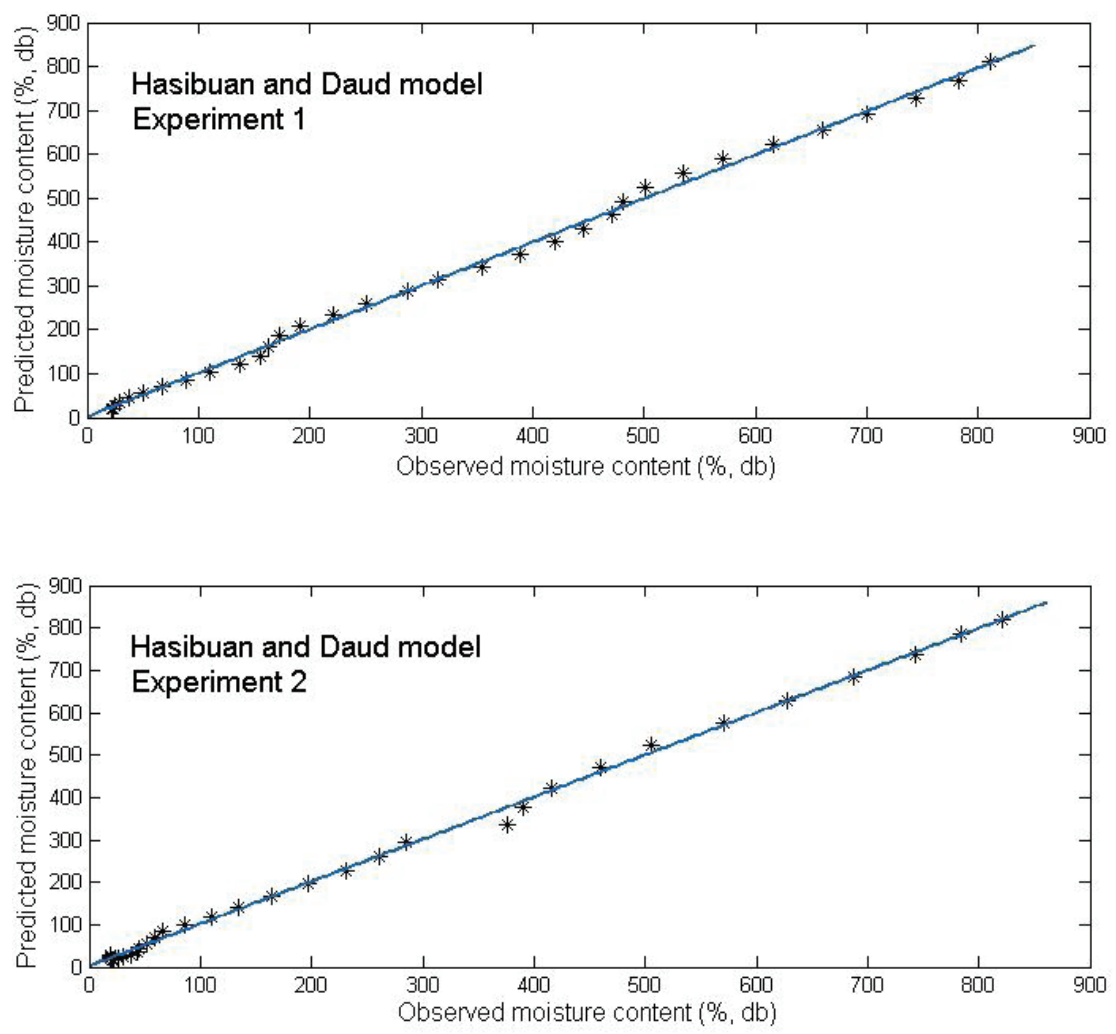

Figure 9. Comparison of predicted and observed moisture content of pineapple in experiment one from Hasibuan and Daud model

\section{Conclusions}

Two pineapple drying experiments were carried out at Silpakorn University during sunny days. Similar data for solar radiation, temperature and relative humidity were obtained for both experiments. During the third day in the second experiment were present some cloudy hours. The results were drawn from the pineapple drying kinetics in a greenhouse-type solar dryer as a basis. Drying curves obtained from experiments showed that the constant drying and the falling drying rate periods exist.

Nine thin-layer drying models were fitted to two experimental data in order to describe the drying characteristics of pineapple. The parameter values, root mean square error (RMSE), mean absolute error (MAE) and modelling efficiency (EFF) of the nine models were calculated. The Hasibuan and Daud model was found to be the best fitting followed by the Sripinyowanich and Modified Midilli. The suitability of the Hasibuan and Daud model was applicable between the prediction and measured values.

\section{ACKNOWLEDGEMENTS}

This research has been supported by CONACYT-México (95103), Solar Energy Research Laboratory, Department of Physic, Faculty of Science and Department of Food Technology, Faculty of Engineering and Industrial Technology at Silpakorn University.

The financial support by Nutrición y Transformación Alimentaria S.A de C.V is highly acknowledged.

\section{RefERenCES}

Agarry, S.E., Ajani, A.E., Aremu, M.O. (2013). Thin layer drying kinetics of pineapple: Effect of blanching temperature-time combination. Nigerian Journal of Basic and Applied Science, 21(1), 1-10. https://dx.doi.org/10.4314/njbas.v21i1.1

Erich, B.J.F., Leo, P., Adan, O.C.G., Samson, R.A. (eds). (2011). Moisture content measurement; Fundamentals of mold growth in indoor environments and strategies for healthy living. Eindhoven, the Netherlands, Wageningen Academic Publishers. 305-334. ISBN 978-90-8686-722-6

Ertekin, C. and Firat, M.Z. (2015). A comprehensive review of thin layer drying models used in agricultural products. Critical Reviews in Food Science and Nutrition. This is a version of an 
unedited manuscript that has been accepted for publication. http://dx.doi.org/10.1080/10408398.2014.910493

Hossain, M.D., Bala, B.K., Hossain, M.A., Mondol, M.R.A. (2001). Sorption isotherms and heat of sorption of pineapple. Journal of Food Engineering, 48(2), 103-107. https://doi.org/10.1016/ S0260-8774(00)00132-1

Janjai, S., Intawee, P., Kaewkiew, J., Sritus, C., Khamvongsa, V. (2011). A large-scale solar greenhouse dryer using polycarbonate: Modeling and testing in a tropical environment of Lao People's Democratic Republic. Renewable Energy. 36(3), 10531062. https://doi.org/10.1016/j.renene.2010.09.008

Janjai, S., Lamlert, N., Intawee, P., Mahayothee, B., Bala, B.K., Nagle, M., Müller, J. (2009). Experimental and simulated performance of a PV-ventilated solar greenhouse dryer for drying of peeled longan and banana. Solar Energy. 83(9), 1550-1565. https://doi.org/10.1016/j.solener.2009.05.003

Janjai, S., Intawee, P., Chaichoet, C., Mahayothee, B., Haewsungcharern, Müller, J. (2006). Improvement of the air flow and temperature distribution in a conventional longan dryer. International Symposium: Towards Sustainable Livelihoods and Ecosystems in Mountainous Regions. March, 1-11.

Janjai, S., Intawee, P., Mahayothee, B., Sruamsiri, P., Khajornpaisan, E., Sangjaroen, A., Boonrod, Y., Bala, B.K., Precoppe, M., Nagle, M., Müller, J. (2012). Performance evaluation of a greenhouse solar dryer for drying longan fruits. Irrigation and processing of tropical fruits. April, 149-150.

John, S.G., Sangamithra, A., Veerapandian, C., Sasikala, S., Sanju, V., Bhuvaneswari, S. (2014). Mathematical modelling of the thin layer drying of banana blossoms. Journal of Nutritional Health and Food Engineering. 1(2), 1-8. https://doi.org/10.15406/ jnhfe.2014.01.00008
Kingsly, A.R.P., Balasubramaniam, V.M., Rastogi, N.K. (2009). Effect of high-pressure processing on texture and drying behavior of pineapple. Journal of Food Process Engineering. 32(3), 369-381. https://doi.org/10.1111/j.1745-4530.2007.00221.x

Koua, K.B., Fassinou, W.F., Gbaha, P., Toure, S. (2009). Mathematical modelling of the thin layer solar drying of banana, mango and cassava. Energy. 34(10), 1594-1602. DOI. https://doi. org/10.1016/j.energy.2009.07.005

Olanipekun B.F., Tunde-Akintunde T.Y., Oyelade, O.J., Adebisi, M.G., Adenaya, T.A. (2014). Mathematical modeling of thinlayer pineapple drying. Journal of Food Processing and Preservation. 2014; 1-11. http://doi.wiley.com/10.1111/jfpp.12362

López-Cerino, I., López-Cruz, I.L., Nagle, M., Mahayothee, B., Müller, J. (2018). Thin layer drying of pineapple (Ananas comosus, L.). Ingeniería Investigación y Tecnología, 19(3). http://dx. doi.org/10.22201/fi.25940732e.2018.19.028

Ramallo L.A. and Mascheroni R.H. (2012). Quality evaluation of pineapple fruit during drying process. Food and Bioproduct processing. 90(2), 275-283. https://doi.org/10.1016/j. fbp.2011.06.001

Simal, S., Femenia, A., Castell-Palou, A., Roselló, C. (2007). Water desorption thermodynamic properties of pineapple. Journal of Food Engineering. 80(4), 1293-1301. https://doi.org/10.1016/j. jfoodeng.2006.10.001

Talla, A., Jannot, Y., Nkeng, G.E., Puiggali, J.R. (2005). Experimental determination and modeling of sorption isotherms of tropical fruits: Banana, Mango and Pineapple. Drying Technology. 23(7), 1477-1498. https://doi.org/10.1081/DRT-200063530

Togrul, I.T. and Pehlivan, D. (2002). Mathematical modeling of solar drying of apricots in thin layers. Journal of Food Engineering. 55(3), 209-216. https://doi.org/10.1016/S0260-8774(02)00065-1 